\title{
Drug-related factors affecting medication adherence among Egyptian asthma patients
}

\author{
Abdellah H K Ali', Esraa Ameen, Kamal Atta and Khaled Fawzy Alkhayat
}

\begin{abstract}
Background: The aim of this study is to evaluate adherence to inhaler therapy in asthmatic patients and examine drug-related factors affecting medication adherence among Egyptian asthma patients. The study was carried out among 110 clinically diagnosed asthma patients attending at a university hospital, Sohag, Egypt. Inhaler criteria and adherence were evaluated by a standardized tool "Morisky Medication Adherence Scale (MMAS), 2008."

Results: The study revealed that out of 110 patients, $42.2 \%$ had a high level, $22.9 \%$ had medium level, and $34.9 \%$ had a low level of medication adherence. There was no relationship between demographic data and medication adherence in asthmatic patients. However, good adherence was frequently encountered among asthmatic patients who used inhaler twice daily, who used drugs its onset of action 5-20 min, who used aerolizer and turbo haler devices, and who used budesonide and budesonide/formoterol.

Conclusions: Poor adherence to inhaler therapy is high in patients with bronchial asthma attending Sohag University Hospital in Upper Egypt. There was a strong relationship between inhaled drug criteria and degree of adherence in asthmatic patients.
\end{abstract}

\section{Background}

Poor adherence to inhaler therapy in patients with bronchial asthma increases mortality, morbidity, and hospital visits $[1,2]$.

Increasing medication adherence is important to increase the benefits of inhaled treatment. So, assessment of the level of adherence to the inhaler therapy in asthmatic patients becomes essential in daily practice [2].

By opposition, poor adherence leads to poor clinical outcomes, an increase in morbidity and mortality, and unnecessary healthcare expenses [3]. Few studies have assessed adherence to asthma medications in Egypt. We aimed to evaluate adherence to inhaled therapy in asthmatic patients and to examine drug-related factors affecting medication adherence.

\section{Methods}

\section{Study subjects and design}

A descriptive cross-sectional study design was used, and 110 asthma patients were selected from the inpatient department and outpatient clinic of chest diseases, Sohag University Hospitals. Before the data collection, this study was approved by the ethical committee of Sohag University Hospitals and an informed consent was taken from the patients.

After taking informed consent from the patients, the informations regarding age, sex, literacy, residence, occupation, smoking habits, socioeconomic status, comorbidities, date of diagnosis of asthma, and pulmonary function tests were recorded.

\footnotetext{
* Correspondence: abdellahdiab@outlook.com

Department of Respiratory Medicine, Sohag Faculty of Medicine, Sohag University, Sohag 82524, Egypt
}

\section{SpringerOpen}

(c) The Author(s). 2020, corrected publication 2020. Open Access This article is licensed under a Creative Commons Attribution 4.0 International License, which permits use, sharing, adaptation, distribution and reproduction in any medium or format, as long as you give appropriate credit to the original author(s) and the source, provide a link to the Creative Commons licence, and indicate if changes were made. The images or other third party material in this article are included in the article's Creative Commons licence, unless indicated otherwise in a credit line to the material. If material is not included in the article's Creative Commons licence and your intended use is not permitted by statutory regulation or exceeds the permitted use, you will need to obtain permission directly from the copyright holder. To view a copy of this licence, visit http://creativecommons.org/ licenses/by/4.0/. 


\section{Inhaler use}

Further questions related to the currently prescribed aerosol therapy for asthma-like number of medications prescribed per day, type of device, type of drug, onset of action of inhaler, and frequency of administration of inhaler.

The current prescribed medications for asthma were identified for all included patients: inhaled steroids (ICS), long-acting $\beta 2$-agonists (LABA), combined LABA/ ICS, short-acting $\beta 2$-agonists, short-acting anticholinergics, and long-acting anticholinergics. Most patients were on combination therapy.

\section{Level of adherence}

Level of adherence was examined by the eight-item Morisky Medication Adherence Scale (MMAS-8) [4]. According to MMAS-8, the level of adherence was high adherence (score, 8), moderate adherence (score, 6 to < $8)$, and low adherence (score, $<6$ ). Patients with low or moderate level of adherence were considered nonadherent.

\section{Statistical analysis}

SPSS version 20 (SPSS Inc., Chicago, IL, USA) was used, and data is presented as mean \pm standard deviations. To compare between groups, $\chi^{2}$ test and the ANOVA test were used. $P$ value of $\leq 0.05$ was considered significant.

\section{Results}

The clinical data of studied patients are depicted in Table 1. A total of 110 included in the study. The age of patients was $39.22 \pm 13.51$ years. Most of the patients were females $(69 / 41 ; 62.72 \%)$. Fifty percent of patients are illiterate. The most commonly used inhaled therapy in asthma patients is presented in Table 1.

As regard frequency of administration of inhaler, it was found that asthma patients were frequently using the inhaler twice daily; also, asthmatic patients used
Table 1 Patients with asthma according to medications

\begin{tabular}{ll}
\hline Variables & Asthma \\
\hline Frequency of administration of inhaler & \\
Once & $3(2.7 \%)$ \\
Twice & $83(75.5 \%)$ \\
On need & $24(21.8 \%)$ \\
Onset of action of inhaler & \\
5 min & $36(32.7 \%)$ \\
20 min & $2(1.9 \%)$ \\
$5-20$ min & $36(32.7 \%)$ \\
30 min & $36(32.7 \%)$ \\
Type of device & \\
Aerolizer & $37(33.6 \%)$ \\
MDI & $23(20.9 \%)$ \\
Turbohaler & $38(34.6 \%)$ \\
Handihaler & $2(1.8 \%)$ \\
Diskus & $7(6.4 \%)$ \\
Breezhaler & $1(0.9 \%)$ \\
Evohaler & $2(1.8 \%)$ \\
Type of drug & \\
Budesonide & $27(24.5 \%)$ \\
Formoterol & $11(10.0 \%)$ \\
Salbutamol & $23(20.9 \%)$ \\
Budesonide/formoterol & $37(33.6 \%)$ \\
Fluticasone/salmetrol & $8(7.4 \%)$ \\
Tiotropium & $1(0.9 \%)$ \\
\hline Ipratropium & $2(1.8 \%)$ \\
\hline I meopyrinum bromide & $1(0.9 \%)$ \\
\hline
\end{tabular}

MDI metered-dose inhaler

the on need more frequently. As regard the onset of action of inhaler, it was found that the inhaler of 5 min of onset of action was frequently used by asthma patients than other types of inhalers. As regard type of device, it was found that aerolizer, metered-dose inhaler (MDI), turbo haler, and hand haler were

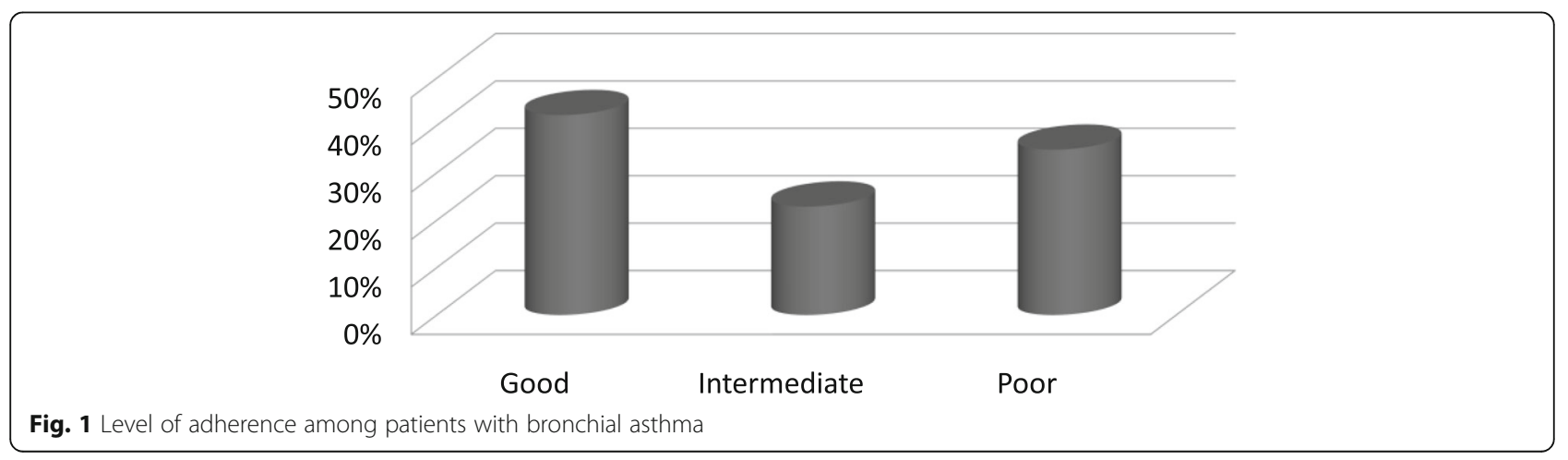


Table 2 Relation between demographic data and adherence pattern in asthmatic patients already on therapy $(n=110)$

\begin{tabular}{|c|c|c|c|c|c|}
\hline Variables & Good & Intermediate & Poor & Total & $P$ value \\
\hline Age/year & $43.82 \pm 13.501$ & $42.61 \pm 13.05$ & $37.56 \pm 15.84$ & $41.86 \pm 14.06$ & 0.082 \\
\hline Gender & & & & & 0.295 \\
\hline Males & $12(26.7 \%)$ & $9(23.7 \%)$ & $11(40.7 \%)$ & $32(29.1 \%)$ & \\
\hline Females & $33(73.3 \%)$ & $29(76.3 \%)$ & $16(59.3 \%)$ & 78 (70.9\%) & \\
\hline Residence & & & & & 0.742 \\
\hline Rural & 19 (42.2\%) & $13(34.2 \%)$ & 11 (40.7\%) & $43(39.1 \%)$ & \\
\hline Urban & $26(57.8 \%)$ & $25(65.8 \%)$ & $16(59.3 \%)$ & $67(60.9 \%)$ & \\
\hline Educational level & & & & & 0.563 \\
\hline Illiterate & $24(53.3 \%)$ & $20(52.6 \%)$ & $11(40.7 \%)$ & $55(50 \%)$ & \\
\hline Primary & $6(13.3 \%)$ & $8(21.1 \%)$ & $4(14.8 \%)$ & $18(16.4 \%)$ & \\
\hline Secondary & $14(31.1 \%)$ & $9(23.7 \%)$ & $9(33.3 \%)$ & $32(29.1 \%)$ & \\
\hline Graduate & $0(0.0 \%)$ & $1(2.6 \%)$ & $1(3.7 \%)$ & $2(1.8 \%)$ & \\
\hline Postgraduate & $1(2.2 \%)$ & $0(0.0 \%)$ & $2(7.4 \%)$ & $3(2.7 \%)$ & \\
\hline Socioeconomic & & & & & 0.05 \\
\hline Low & $0(0.0 \%)$ & $2(5.3 \%)$ & $2(7.4 \%)$ & $4(3.6 \%)$ & \\
\hline Middle & 45 (100\%) & $36(94.7 \%)$ & $23(85.2 \%)$ & $104(94.5 \%)$ & \\
\hline High & $0(0.0 \%)$ & $0(0.0 \%)$ & $2(7.4 \%)$ & $2(1.8 \%)$ & \\
\hline Smoking status & & & & & 0.289 \\
\hline Non & $42(93.3 \%)$ & $34(89.5 \%)$ & $21(77.8 \%)$ & $97(88.2 \%)$ & \\
\hline Ex-smoker & $3(6.7 \%)$ & $3(7.9 \%)$ & $3(11.1 \%)$ & $9(8.2 \%)$ & \\
\hline Stop smoking & $0(0.0 \%)$ & $1(2.6 \%)$ & $2(7.4 \%)$ & $3(2.7 \%)$ & \\
\hline Current smoker & $0(0.0 \%)$ & $0(0.0 \%)$ & $1(3.7 \%)$ & $1(0.9 \%)$ & \\
\hline Smoking index & & & & & 0.797 \\
\hline Mild & $1(50 \%)$ & $0(0.0 \%)$ & $2(40 \%)$ & $3(37.5 \%)$ & \\
\hline Moderate & $0(0.0 \%)$ & $0(0.0 \%)$ & $1(20 \%)$ & $1(12.5 \%)$ & \\
\hline Heavy & $1(50 \%)$ & $1(100 \%)$ & $2(40 \%)$ & $4(50 \%)$ & \\
\hline Degree of asthma & & & & & 0.082 \\
\hline Intermittent & $32(45.7 \%)$ & $8(21.1 \%)$ & $21(36.2 \%)$ & $61(36.7 \%)$ & \\
\hline Mild persistent & $4(5.7 \%)$ & $9(23.7 \%)$ & $10(17.2 \%)$ & $23(13.9 \%)$ & \\
\hline Moderate persistent & $25(35.7 \%)$ & $15(39.5 \%)$ & $21(36.2 \%)$ & $61(36.7 \%)$ & \\
\hline Severe persistent & 9 (12.9\%) & $6(15.8 \%)$ & $6(10.3 \%)$ & $21(12.7 \%)$ & \\
\hline Duration of disease & $14.49 \pm 9.36$ & $11.74 \pm 8.45$ & $10.83 \pm 10.32$ & $12.64 \pm 10$ & 0.097 \\
\hline No. of emergency visit/last year & & & & & 0.231 \\
\hline 1 visits & $35(77.8 \%)$ & $34(89.5 \%)$ & 19 (70.4\%) & $88(80 \%)$ & \\
\hline $2-4$ visits & $7(15.6 \%)$ & $4(10.5 \%)$ & $7(25.9 \%)$ & $18(16.4 \%)$ & \\
\hline$>4$ visits & $3(6.7 \%)$ & $0(0.0 \%)$ & $1(3.7 \%)$ & $4(3.6 \%)$ & \\
\hline No. comorbidities & $27(32.53 \%)$ & $31(37.34 \%)$ & $25(30.13 \%)$ & & 0.153 \\
\hline 1 comorbidities & $11(40.74 \%)$ & 9 (33.33\%) & 7 (25.93\%) & $83(75.45 \%)$ & \\
\hline$\geq 2$ comorbidities & & & & $27(24.55 \%)$ & \\
\hline
\end{tabular}


frequently used by asthma in order than other types of devices. As regard type of drug, it was found that budesonide, formoterol, salbutamol, and budesonide/ formoterol were frequently used by asthma in order than other types of drugs.

The different categories of adherence are shown in Fig. 1. A total of $42.2 \%$ of patients had good adherence, $22.9 \%$ intermediate adherence, and $34.9 \%$ poor adherence.

Table 2 shows the relation between demographic data and adherence in asthmatic patients already on inhaler therapy. No significant relationship between demographic data and medication adherence was found in asthmatic patients $(P>0.05)$.

The relation between drug characteristics and adherence patterns in asthma patients already on therapy is shown in Table 3 (Fig. 2 a-d). Adherence pattern was significantly associated with frequency of administration, onset of action, type of device, type of drug with $P=(0.001,0.002,0.001,0.001)$ respectively. It was found that good adherence frequently encountered among patients who used inhaler twice daily, who used drugs its onset of action < 5$20 \mathrm{~min}$, who used aerolizer and turbo haler, and who used budesonide/formoterol and budesonide only.

\section{Discussion}

Poor adherence was associated with poor clinical outcomes among asthma patients. So that our study aimed at determining factors affecting inhaled therapy adherence in asthma patients using the MMAS- 8 $[5,6]$.

The study was conducted in 110 asthma patients among which 69 were female and the other 41 were male. The mean age was of $39.22 \pm 13.51$ years. A total of $52.72 \%$ came from urban area, $86.36 \%$ had middle socioeconomic class, and $50 \%$ was illiterate. The duration of asthma was $11.21 \pm 8.91$ years. More than half $(75.45 \%)$ of the patients had one comorbidity.

Table 3 Relation between drug characteristics and adherence pattern in asthmatic patients already on therapy $(n=110)$

\begin{tabular}{|c|c|c|c|c|c|}
\hline Variables & Good & Intermediate & Poor & Total & $P$ value \\
\hline Frequency of inhaler administration & & & & & $<0.001$ \\
\hline Once & $0(0.0 \%)$ & $2(5.3 \%)$ & $1(3.7 \%)$ & $3(2.7 \%)$ & \\
\hline Twice & $40(88.9 \%)$ & $32(84.2 \%)$ & $11(40.7 \%)$ & $83(75.5 \%)$ & \\
\hline On need & $5(11.1 \%)$ & $4(10.5 \%)$ & $15(55.6 \%)$ & $24(21.8 \%)$ & \\
\hline Onset of action of inhaler & & & & & 0.002 \\
\hline$<5-20 \min$ & $13(28.9 \%)$ & $19(50 \%)$ & $4(14.8 \%)$ & $36(32.7 \%)$ & \\
\hline $5 \mathrm{~min}$ & $13(28.9 \%)$ & $8(21.1 \%)$ & $15(55.6 \%)$ & $36(32.7 \%)$ & \\
\hline $20 \mathrm{~min}$ & $0(0.0 \%)$ & $0(0.0 \%)$ & $2(7.4 \%)$ & $2(1.9 \%)$ & \\
\hline $30 \mathrm{~min}$ & $19(42.2 \%)$ & $11(28.9 \%)$ & $6(22.2 \%)$ & $36(32.7 \%)$ & \\
\hline Type of device & & & & & 0.001 \\
\hline Aerolizer & $20(44.5 \%)$ & $13(34.2 \%)$ & $4(14.8 \%)$ & $37(33.6 \%)$ & \\
\hline MDI & $5(11.1 \%)$ & $4(10.6 \%)$ & $14(51.9 \%)$ & $23(20.9 \%)$ & \\
\hline Turbohaler & $14(31.1 \%)$ & $19(50.0 \%)$ & $5(18.5 \%)$ & $38(34.5 \%)$ & \\
\hline Handihaler & $0(0.0 \%)$ & $1(2.6 \%)$ & $1(3.7 \%)$ & $2(1.8 \%)$ & \\
\hline Diskus & $4(8.9 \%)$ & $1(2.6 \%)$ & $2(7.4 \%)$ & $7(6.4 \%)$ & \\
\hline Breezhaler & $0(0.0 \%)$ & $0(0.0 \%)$ & $1(3.7 \%)$ & $1(0.9 \%)$ & \\
\hline Evohaler & $2(4.4 \%)$ & $0(0.0 \%)$ & $0(0.0 \%)$ & $2(1.8 \%)$ & \\
\hline Type of drug & & & & & 0.001 \\
\hline Budesonide & $15(33.4 \%)$ & $9(23.8 \%)$ & $3(11.1 \%)$ & $27(24.5 \%)$ & \\
\hline Formoterol & $6(13.3 \%)$ & $4(10.5 \%)$ & $1(3.7 \%)$ & $11(10 \%)$ & \\
\hline Salbutamol & $5(11.1 \%)$ & $4(10.5 \%)$ & $14(51.9 \%)$ & $23(20.9 \%)$ & \\
\hline Budesonide/formoterol & $13(28.9 \%)$ & 19 (50\%) & $5(18.5 \%)$ & $37(33.6 \%)$ & \\
\hline Fluticasone/salmetrol & $6(13.3 \%)$ & $1(2.6 \%)$ & $1(3.7 \%)$ & $8(7.3 \%)$ & \\
\hline Glycopyrinum & $0(0.0 \%)$ & $0(0.0 \%)$ & $1(3.7 \%)$ & $1(0.9 \%)$ & \\
\hline Tiotropium & $0(0.0 \%)$ & $1(2.6 \%)$ & $1(3.7 \%)$ & $2(1.8 \%)$ & \\
\hline Ipratropium & $0(0.0 \%)$ & $0(0.0 \%)$ & $1(3.7 \%)$ & $1(0.9 \%)$ & \\
\hline
\end{tabular}

$N . B$ number of drug used more than patients as some patients use more than one drug, MDI metered-dose inhaler 


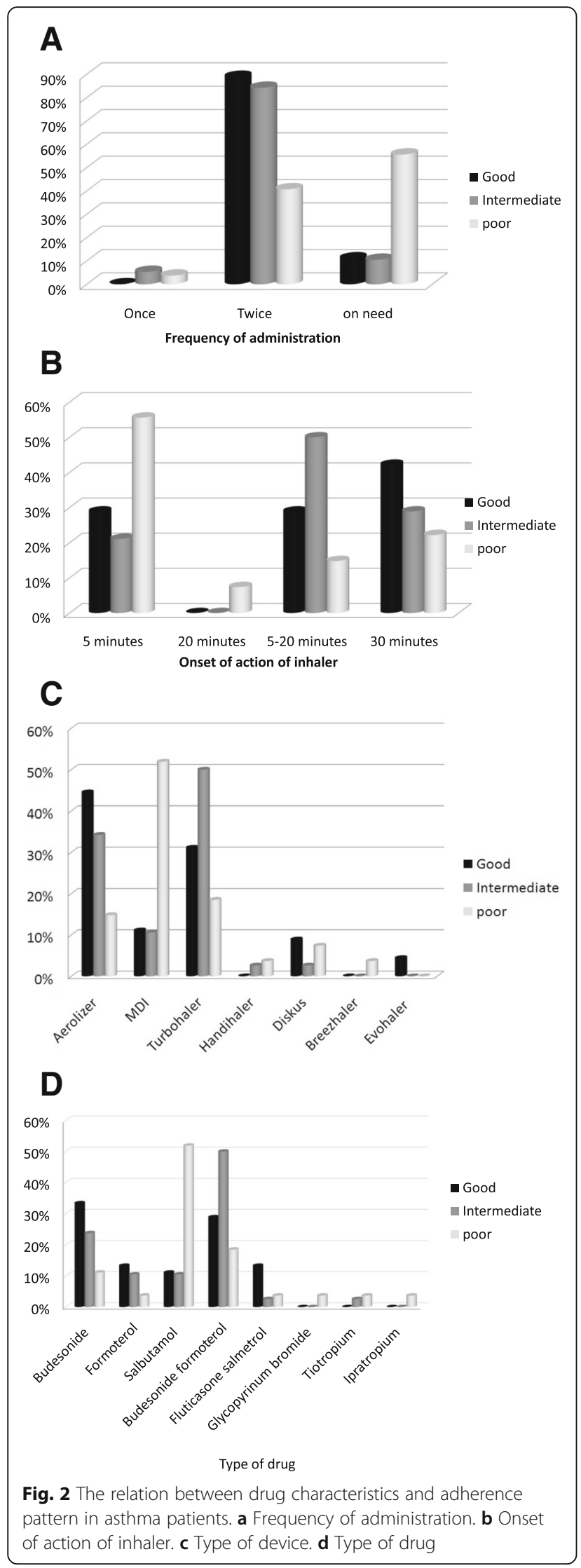

Among the studied population, poor adherence was observed in $34.9 \%, 22.9 \%$ intermediate adherence, and $42.2 \%$ of patients had good adherence. This result matches with the results of those who found that adherence among asthmatic patients was $49 \%[7,8]$. These results show that many patients with bronchial asthma are not adherent to their inhaled therapy. A previous study shows that inhaled therapy adherence is worse than other medications in asthmatic patients [9-12]. In other studies, medication adherence rates have consistently been shown to be $30-40 \%$ and may increase as high as $70 \%$ among asthma patients $[9,13-16]$. This discrepancy in findings may be due to the difference in knowledge regarding asthma among participants, the use of different questionnaires, and the inclusion of different groups of the sample population in the study.

In this study, none of the sociodemographic informations (such as age, gender, place of residence, educational status, comorbidity, severity of symptoms, and smoking habit) were associated with patients' level of medication adherence. Consistent to these findings, Senior et al. showed that patients' level of medication adherence was not associated with sociodemographic and clinical variables (age, gender, marital status, and place of residence, education, type of occupation and current smoking status, and severity of asthma [17]. However, these findings are contradictory with other studies [18]. The difference in findings might be due to the inclusion of patients of different duration of disease, different study designs, and use of different validated questionnaires in the studies.

As regard frequency of administration of inhaler in our study, we found that $75.5 \%$ preferred twice-daily therapy, $2.7 \%$ preferred once daily, and $21.8 \%$ used inhaler on need. There was a statistically significant association between good adherence and the use of inhaler twice daily in asthmatic patients in comparison with the use of on-need inhaler. However, this result is not comparable with Venables et al. [19]. Other studies found that adherence in asthmatic patients were unrelated to frequent uses of inhaler therapy [20-22]. Others observed that reliever inhalers were frequently used in asthmatic patients $[23,24]$.

As regard onset of action of inhaler, we found that the inhaler of 5-20 min of onset of action was frequently used by patients than other types of inhalers and this was statistically significant, this result due to asthma patients almost always complaining and need rescue bronchodilators medications which are rapidly acting, also, the drug-delivering its action 
rapidly lead the patient to continue taking the drug daily [25].

In our study, there was a statistically significant association between adherence and the use of turbo haler and aerolizer in asthmatic patients in comparison with the use of MDI. Our study result agrees with a previous study, which found that using dry-powder inhalers (DPIs) versus metered-dose inhalers (MDIs) was associated to adherence [26].

Moreover, a significant relationship was found between good adherence and budesonide/formoterol and budesonide in asthmatic patients in comparison with the use of salbutamol. This observation agrees with that of Axelsson et al. [27] and Stempel et al. [28]

\section{Conclusion}

Adherence to inhaler therapy is low in Egyptian asthmatics. Type of device, type of drug, onset of action of inhaler, and frequency of administration of inhaler significantly affect medication adherence in asthma patients.

\section{Abbreviations}

ICS: Inhaled steroids; LABA: Long-acting ß2-agonists; MMAS-8: Eight-item Morisky Medication Adherence Scale; SPSS: Statistical Package for the Social Sciences; MDI: Metered-dose inhaler; DPIs: Dry-powder inhalers

\section{Acknowledgements}

Deep gratitude to all patients accepted to participate in the study.

\section{Authors'contributions}

Abdellah Hamed, Kamal Atta, and Khaled Fwazy put the design of the work, interpreted the data, writing the manuscript, and revised it. Esraa Ameen performed the procedure, data acquisition, analysis, and a contributor in writing the manuscript. All authors have read and approved the final manuscript.

\section{Funding}

Not available.

\section{Availability of data and materials}

The datasets used during the current study are available from the corresponding author on reasonable request.

\section{Ethics approval and consent to participate}

Before the data collection, this study was approved by the ethical committee of Sohag University Hospitals and an informed consent was taken from the patients.

\section{Consent for publication}

Not applicable.

\section{Competing interests}

The authors declare that they have no competing interests.

Received: 8 July 2020 Accepted: 2 October 2020

Published online: 20 October 2020

\section{References}

1. Melani AS, BonaviaM CV, Cinti C, Lodi M, Martucci P et al (2011) Gruppo Educazionale Associazione Italiana Pneumologi Ospedalieri: inhaler mishandling remains common in real life and is associated with reduced disease control. Respir Med 105:930-938

2. Rau JL (2005) Determinants of patient adherence to aerosol regimen. Respir Care 50:1346-1356
3. Brown, Marie T.; Bussell, Jennifer K (2011). Medication adherence: WHO cares. In: Mayo Clinic Proceedings. Elsevier, . P. 304-314.

4. Morisky DE, Ang A, Krousel-Wood M, Ward HJ (2008) Predictive validity of a medication adherence measure in an outpatient setting. J Clin Hypertens 10:348-354

5. Chiu KC, Boonsawat W, Cho SH (2014) Patients' beliefs and behaviors related to treatment adherence in patients with asthma requiring maintenance treatment in Asia. J Asthma 51(6):652-659

6. Baker CL, Gupta S, Goren A, Willke RJ (2013) Adherence and satisfaction with oral versus other treatments among patients with chronic obstructive pulmonary disease (COPD) in the U.S. 2012 national health and wellness survey. Value Health 16(3):A236-A237

7. Nizar Rifaat, Elham Abdel-Hady and Ali A. Hasan (2013) Egyptian Journal of Chest Diseases and Tuberculosis 62, 371-376.

8. Ayele AA, Tegegn HG (2017) Non adherence to inhalational medications and associated factors among patients with asthma in a referral hospital in Ethiopia, using validated tool TAl. Asthma Res Pract 3:7

9. Jones C, Santanello NC, Boccuzzi SJ, Wogen J, Strub P, Nelsen LM (2003) Adherence to prescribed treatment for asthma: evidence from pharmacy benefits data. J Asthma 40:93e101

10. McNally KA, Rohan J, Schluchter M, Riekert KA, Vavrek P, Schmidt A et al (2009) Adherence to combined montelukast and fluticasone treatment in economically disadvantaged African American youth with asthma. J Asthma 46:921e7

11. Fitzpatrick AM, Kir T, Naeher LP, Fuhrman SC, Hahn K, Teague WG (2009) Tablet and inhaled controller medication refill frequencies in children with asthma. J Pediatr Nurs 24:81e9

12. Rand C, Bilderback A, Schiller K, Edelman JM, Hustad CM, Zeiger RS et al (2007) Adherence with montelukast or fluticasone in a long-term clinical trial: results from the mild asthma montelukast versus inhaled corticosteroid trial. J Allergy Clin Immunol 119:916e23

13. Bozek A, Jarzab J (2010) Adherence to asthma therapy in elderly patients. J Asthma 47:162-165

14. Latry P, Pinet M, Labat A, Magand JP, Peter C, Robinson P et al (2008) Adherence to anti-inflammatory treatment for asthma in clinical practice in France. Clin Ther 30:1058-1068

15. Clerisme-Beaty EM, Bartlett SJ, Teague WG, Lima J, Irvin CG, Cohen R (2011) The Madison avenue effect: how drug presentation style influences adherence and outcome in patients with asthma. J Allergy Clin Immunol 127:406-411

16. Rand CS, Wise RA (1994) Measuring adherence to asthma medication regimens. Am J Respir Crit Care Med 149:69-78

17. Senior V, Marteau TM, Weinman J (2004) Self-reported adherence to cholesterol-lowering medication in patients with familial hyper cholesterolaemia: the role of illness perceptions. 18(6):475-481

18. Hertz RB, Unger AN, Lustik MB (2005) Adherence with pharmacotherapy for type 2 diabetes: a retrospective cohort study of adults with employersponsored health insurance. Clin.Ther. 27:1064-1073

19. Venables T (1996) A comparison of the efficacy and patient acceptability of once daily budesonide via turbohaler and twice daily fluticasone propionate via disc-inhaler at an equal daily dose of $400 \mu \mathrm{g}$ in adult asthmatics. $\mathrm{Br}$ Clin Pharmacol 7:15-32

20. van Schayck CP, Bijl-Hofland ID, Folgering H, Cloosterman SG, Akkermans R, van den Elshout $F$ et al (2002) Influence of two different inhalation devices on therapy compliance in asthmatic patients. Scand Prim Health Care 20:126-128

21. Laforest L, El Hasnaoui A, Pribil C, Ritleng C, Osman LM, Schwalm MS et al (2009) Asthma patients' self-reported behaviours toward inhaled corticosteroids. Respir Med 103:1366-1375

22. Wells KE, Peterson EL, Ahmedani BK, Williams LK (2013) Real-world effects of once vs. greater daily inhaled corticosteroid dosing on medication adherence. Ann Allergy Asthma Immunol 111:216-220

23. Bender BG, Apter A, Bogen DK, Dickinson P, Fisher L, Wamboldt FS et al (2010) Test of an interactive voice response intervention to improve adherence to controller medications in adults with asthma. J Am Board Fam Med 23:159e65

24. Apter AJ, Reisine ST, Affleck G, Barrows E, ZuWallack RL (1998) Adherence with twice-daily dosing of inhaled steroids. Socioeconomic and healthbelief differences. Am J Respir Crit Care Med 157:1810-1817

25. Sanduzzi A, Balbo P, Candoli P, Catapano GA, Contini P, Mattei A et al (2014) COPD: adherence to therapy. Multidiscip Respir Med 9(1):60 
26. Friedman HS, Navaratnam P, McLaughlin J (2010) Adherence and asthma control with mometasone furoate versus fluticasone propionate in adolescents and young adults with mild asthma. J Asthma 47:994-1000

27. Axelsson M, Emilsson M, Brink E, Lundgren J, Torén K, Lötvall J (2009)

Personality, adherence, asthma control and health-related quality of life in young adult asthmatics. Respir Med 103:1033-1040

28. Stempel DA, Stoloff SW, Carranza Rosenzweig JR, Stanford RH, Ryskina KL, Legorreta AP (2005) Adherence to asthma controller medication regimens. Respir Med 99:1263-1267

\section{Publisher's Note}

Springer Nature remains neutral with regard to jurisdictional claims in published maps and institutional affiliations.

\section{Submit your manuscript to a SpringerOpen ${ }^{\circ}$ journal and benefit from:}

- Convenient online submission

- Rigorous peer review

- Open access: articles freely available online

High visibility within the field

- Retaining the copyright to your article

Submit your next manuscript at $\boldsymbol{\nabla}$ springeropen.com 